\title{
On the formation of family-group names and gender of genera based on the stem-butis (Teleostei: Perciformes: Gobioidei)
}

\author{
ANTHONY C. GILL ${ }^{1} \&$ DOUGLAS F. HOESE ${ }^{2}$ \\ ${ }^{1}$ Macleay Museum and School of Biological Sciences, Macleay Building A12, University of Sydney, New South Wales, 2006, Australia. \\ E-mail: anthony.c.gill@sydney.edu.au \\ ${ }^{2}$ Australian Museum, 6 College Street Sydney, New South Wales, 2010, Australia. E-mail: doug.hoese@austmus.gov.au
}

The familial classification of gobioid fishes is in a state of flux, reflecting incomplete understanding of phylogenetic relationships within the suborder. However, there has been rapid progress over the past decade or so, which is likely to continue, undoubtedly leading to the erection of new family-group names. One such family, Odontobutidae, was erected by Hoese and Gill (1993) for several Asiatic freshwater genera. Recently, the spelling of this taxon has been challenged (Kottelat, 2001; Chen et al., 2002). According to Chen et al. (2002: 233): "Although commonly spelled Odontobutidae, a family-group name based on the genus group name Odontobutis should be spelled Odontobutididae as the stem of the genus group name is odontobutid- (ICZN art. 29). The spelling Odontobutidae can be retained under ICZN art. 29.3.1.1 only if it is the "prevailing usage", but ICZN is logically flawed on this point as it does not provide a tool to objectively decide what is the "prevailing usage". Both spellings are in use, and it seems thus logical to stick to the letter of the ICZN."

The purpose of this note primarily is to clarify the spelling of this family group name, and, by extension, of other current or potential family-group names based on the stem-butis (e.g., Butidae Bleeker; names formed from Gymnobutis Bleeker, Neodontobutis Chen, Kottelat \& Wu, Prionobutis Bleeker). Each of these names is ultimately based on Cheilodipterus butis Hamilton, the type species (by tautonymy) of Butis Bleeker.

Chen et al. (2002) did not provide an explicit justification for an odontobutid- stem, but presumably their case rests specifically on Article 29.3.1 of the ICZN: "If a generic name is or ends in a Greek or Latin word, or ends in a Greek or Latin suffix, the stem for the purposes of the Codes is found by deleting the case ending of the appropriate genitive singular." Surprisingly, however, they did not demonstrate an origin for the name, but presumably assumed it was Greek because of the $-i$ s ending.

Hamilton (1822) offered no explanation for the origin of his name C. butis. We therefore searched Greek and Latin dictionaries in the extensive library of the Natural History Museum, London, but were unable to find any reference to butis. However, a search of Indian literature revealed a match: butis (buti-singular) is a decorative, circular design woven, embroidered or printed on cloth, and is particularly common in sari fabric. Butis designs usually contrast vividly with the background fabric, e.g., orange, gold, yellow, red or white over a dark field colour (Bhattacharyya, 1995 ; S. Guha, pers. comm.). We believe that Hamilton's name refers to this butis. Our interpretation is in keeping with Hamilton's description of the live colours of $C$. butis: "[it] is of a blackish colour, with the hinder fins spotted with red, and ventrals with black. There are two red spots at the roots of the pectoral fins" (Hamilton, 1822: 57). Moreover, Hamilton (1822) also used unchanged Indian words for numerous other species he described (e.g., Cyprinus aprana, Cobitus balgara, Cyprinus barna, Cyprinus bhola, Ophisurus boro, Platystacus chaca, Gobius gutum, Ophisurus harancha).

Given this interpretation - that butis is not of Greek or Latin origin—the case falls under Article 29.3.3: "If a generic name is or ends in a word not Greek or Latin, or is an arbitrary combination of letters, the stem for the purposes of the Code is that adopted by the author who establishes the new family-group taxon [...]"

Therefore, the spelling proposed by Hoese and Gill (1993), Odontobutidae, is to be retained. Similarly, the spelling of Butidae Bleeker 1874 (originally as Butii), should be also retained. The spelling of new family group names based on genera ending in -butis would be determined by the authors of those names. However, in the interest of consistency, we advocate the use of a -but stem rather than -butid stem.

Also relevant to this issue is the gender of generic names formed from the -butis stem. Article 30.2 of the Code treats generic names formed from words that are neither Latin nor Greek. Considering other issues (origin not from a 
modern European language), the gender of such names is determined on a case-by-case basis, depending on whether: gender is expressly specified by the author of the genus (art. 30.2.2); if no gender is indicated, then on the gender of species originally included in the genus (art. 30.2.3); if neither of the above, then the name is to be treated as masculine, unless the name ends in $-\mathrm{a}$ (feminine) or $-\mathrm{um}$, -on or $-\mathrm{u}$ (neuter) (art 30.2.4). Each genus is discussed below.

Butis Bleeker. Bleeker (1856: 142) divided Eleotris into various groups, and indicated that Eleotris butis of Cantor would take the name Butis. Cantor (1849) referred to Eleotris butis, attributing it to Cheilodipterus butis of Hamilton (1822). That usage would make Cheilodipterus butis the type species by tautonomy. No specific epithet (i.e., butis or any other species) was used directly in combination with Butis, consequently there is no indication of gender and under the code Butis should be regarded as masculine. In a subsequent paper Bleeker (1857a) assigned Eleotris gymnopomus Bleeker (1853) to Butis, retaining a masculine termination for the specific epithet. However, in a different publication that same year (Bleeker, 1857b) he referred to Butis melanostigma (Bleeker, 1849). It is therefore apparent that Bleeker was not consistent in applying appropriate gender ending and often simply listed the original spelling when transferring species from one genus to another. In 1859 he listed numerous species in Butis and only changed Eleotris prismatica Bleeker to Butis prismaticus, implying that he regarded Butis as masculine. In his major work on gobioid fishes (Bleeker, 1874) he listed Butis butis Bleeker as the type. We conclude that Butis is masculine.

Gymnobutis Bleeker. Bleeker (1874) included only the type species, Eleotris gymnocephalus Steindachner (1866). The genus should therefore be treated as masculine under art. 30.2.3. Gymnobutis is a synonym of Philypnodon Bleeker (1874) (Hoese \& Reader, 2006), and both genera were described in the same paper by Bleeker. Waite (1904) appears to be the first reviser in regarding Gymnobutis as a junior synonym of Philypnodon.

Neodontobutis Chen, Kotttelat \& Wu. The authors of this genus explicitly stated that the gender of the genus is feminine (Chen et al., 2002: 230), which is to be retained under art. 30.2.2.

Odontobutis Bleeker. Bleeker (1874) included only the type species, Eleotris obscura Temminck \& Schlegel (1845), so the genus should be treated as feminine under art. 30.2.3.

Prionobutis Bleeker. Bleeker (1874) included only the type species, Eleotris dasyrhynchus Günther (1868), so the genus should be treated as masculine under art. 30.2.3.

We have searched Bleeker papers both manually and electronically and not found earlier usage of the names listed above.

\section{Acknowledgements}

We thank J. Philp and S. Guha for confirmation of our understanding of the word butis. H.K. Larson read and commented on a manuscript draft. This work was supported by NSF award DEB-0541914 to the first author while at Arizona State University.

\section{References}

Bhattacharyya, A.K. (1995) A Pageant of Indian Culture: Art and Archaeology. Abhinav Publications, New Dehli, 346 pp.

Bleeker, P. (1849) Bijdrage tot de kennis der Blennioïden en Gobioïden van der Soenda-Molukschen Archipel, met beschrijving van 42 nieuwe soorten. Verhandelingen van het Bataviaasch Genootschap van Kunsten en Wetenschappen, 22, 140.

Bleeker, P. (1853) Diagnostische beschrijvingen van nieuwe of weinig bekende vischsoorten van Sumatra. Tiental V-X. Natuurkundig Tijdschrift voor Nederlandsch Indië, 4, 243-302.

Bleeker, P. (1856) Bijdrage tot de kennis der ichthyologische fauna van het eiland Boeroe. Natuurkundig Tijdschrift voor Nederlandsch Indië, 11, 383-414.

Bleeker, P. (1857a) Bijdrage tot de kennis der ichthyologische fauna van het eiland Nias. Natuurkundig Tijdschrift voor Nederlandsch Indie, 12, 211-228.

Bleeker, P. (1857b) Tiende bijdrage tot de kennis der ichthyologische fauna van Borneo. Visschen van de rivieren Barito, Kahajan en Kapoeas. Acta Societatis Regiae Scientiarum Indo-Neêrlandicae, 2, 1-21.

Bleeker, P. (1859) Enumeratio specierum piscium hucusque in Archipelago indico observatarum, adjectis habitationibus citationibusque, ubi descriptiones earum recentiores reperiuntur, nec non speciebus Musei Bleekeriani Bengalensibus, Japonicis, Capensibus Tasmanicisque. Acta Societatis Regiae Scientiarum Indo-Nê̂rlandicae, 6, 1276.

Bleeker, P. (1874) Esquisse d'un système naturel des Gobioïdes. Archives néerlandaises des sciences exactes et 
naturelles, 9, 289-331.

Cantor, T.E. (1849) Catalogue of Malayan fishes. Journal and Proceedings of the Asiatic Society of Bengal, 18, i-xii + 983-1443, pls. 1-14.

Chen, I-S., Kottelat, M. \& Wu, H.L. (2002) A new genus of freshwater sleeper (Teleostei: Odontobutididae) from southern China and mainland Southeast Asia. Journal of the Fisheries Society of Taiwan, 29, 229-235.

Günther, A. (1868) Description of two new gobioid fishes from Sarawak. Annals and Magazine of Natural History, (series 4), 1, 264-266, pl. 12.

Hamilton, F. (1822) An Account of the Fishes Found in the River Ganges and its Branches. Edinburgh \& London. i-vii + 1-405, pls. 1-39.

Hoese, D.F. \& Gill, A.C. (1993) Phylogenetic relationships of eleotridid fishes (Perciformes: Gobioidei). Bulletin of Marine Science, 52, 415-440.

Hoese, D.F. \& Reader, S. (2006) Description of a new species of dwarf Philypnodon (Teleostei: Gobioidei: Eleotridae) from south-eastern Australia. Memoirs of Museum Victoria, 63, 15-19.

Kottelat, M. (2001) Fishes of Laos. WHT Publications (Pte) Ltd., 198 pp.

Steindachner, F. (1866) Über die Fische von Port Jackson in Australien. Anzeiger der Kaiserlichen Akademie der Wissenschaften, Mathematisch-Naturwissenschaftlichen Classe, 3, 50-54.

Temminck, C.J. \& Schlegel, H. (1845) Fauna Japonica, sive descriptio animalium quae in itinere per Japoniam suscepto annis 1823-30 collegit, notis observationibus et adumbrationibus illustravit P. F. de Siebold. Fauna Japonica, sive descriptio animalium quae in itinere per Japoniam ... Parts 7-9, 113-172, pls. 1-143 + A.

Waite, E.R. (1904) A review of the eleotrids of New South Wales. Records of the Australian Museum, 5, $277-286$. 